\section{Concern grows for Turkey's academics}

We strongly urge the Turkish government to stop prosecuting academics, to abide by international human-rights values and to respect civil liberties - including freedom of speech (see Nature http://doi. org/bbxj; 2016).

In a petition to the government this month, more than 2,000 academics from Turkey and thousands of international scholars have called for an end to the curfews and violence against people in Kurdish provinces. This prompted Turkey's President Recep Tayyip Erdoğan to order the Higher Education Board to take action against those academics he described as committing "treason". Istanbul's Chief Public Prosecutor launched a criminal investigation based on Article 301 of the Turkish Penal Code, which prosecutes those who insult the state.

We are deeply concerned about this escalating crisis. We hope that the international academic community will join us in condemning these attacks against our colleagues in Turkey. Caghan Kizil ${ }^{*}$ German Centre for Neurodegenerative Diseases, Helmholtz Association, Dresden, Germany.

caghan.kizil@crt-dresden.de *Supported by 14 signatories (listed at go.nature.com/jy8ol6).

\section{Synthesize evidence to steer decisions}

Using evidence mapping to display and categorize environmental studies cannot replace 'evidence synthesis' in guiding decision-making (M.C. McKinnon et al. Nature 528, 185-187; 2015). There are no shortcuts to evidence-based practice.

The results of investigations need to be synthesized to allow conclusions to be drawn from contradicting data (L. V. Dicks et al. Trends Ecol. Evol. 29,
607-613; 2014). Studies can be assigned a 'level of evidence' indicator of design and quality, which is derived from evidence hierarchies (see, for example, A.-C. Mupepele et al. Ecol. Appl. http://dx.doi.org/10.1890/150595.1; 2016). This indicator reflects the confidence with which the reported outcome can be causally attributed to the investigated driver.

Practitioners' questions are rarely answered directly by an existing set of studies. Evidencebased medicine tackles this problem by developing clinical guidelines on the basis of collated scientific results and clinical experience, and by using systematic reviews of research results and evidence assessments that are supported by hierarchies. Anne-Christine Mupepele, Carsten F. Dormann University of Freiburg, Germany. anne-christine.mupepele@biom. uni-freiburg.de

\section{Hold atmosphere in trust for all}

We, the undersigned, call on the V20 - the 20 countries that are most vulnerable to the effects of climate change - to take the lead in creating an 'atmospheric trust' that establishes community property rights over the atmospheric commons (www.claimthesky.org). The V20 could use this trust as a legal instrument to address the climate crisis and to help to implement last month's Paris agreement to keep warming well below $2^{\circ} \mathrm{C}$.

Under public-trust doctrine, certain natural resources such as soil and water must be held in trust to serve the public good. It is every government's responsibility as a trustee to protect these assets as natural capital and to maintain them for the public's use, not give them away or sell them to private parties. The global atmosphere is one such asset.

An atmospheric trust would act as an independent agency and trustee. It could collect claims for damages to the atmosphere and invest funds in mitigation, adaptation and compensation, and in resources for the most affected populations. Because only 90 enterprises (mainly extractive industries) are responsible for two-thirds of global carbon emissions (R. Heede Clim. Change 122, 229-241; 2014), damage claims could target a relatively small number of entities.

All governments would eventually be co-trustees in the atmospheric commons, with a fiduciary responsibility to protect it from catastrophic releases of greenhouse gases.

Robert Costanza ${ }^{\star}$ The Australian National University, Acton, Australia.

robert.costanza@anu.edu.au ${ }^{*}$ On behalf of 31 correspondents (see go.nature.com/52f8mt for full list).

\section{What stops women getting more grants?}

Women make up 33\% of the applicants who are eligible for programmes funded by the UK Biotechnology and Biological Sciences Research Council (BBSRC), but they lead only $21 \%$ of grant applications. The percentage receiving large grants of more than $£ 2$ million (US\$2.8 million) remains stubbornly low: in 2014, women had a success rate of $17 \%$ compared with $44 \%$ for men. To investigate this, we informally surveyed focus groups from seven BBSRC-funded universities (see go.nature.com/wqrfz3).

All groups cited society's expectations of professional women and (unconscious) biases against them. They also specified the way in which science as a profession organizes itself and how esteem is rewarded; and dominant behaviours by fulltime researchers (primarily men) that seem to attract support at the expense of more-junior, parttime or flexitime researchers (primarily women). There were perceived inconsistencies in the grant-award process, including in the quality and tone of reviewer comments and committee feedback, and concerns about gender imbalance in the reviewer pool.

The BBSRC is working with its research communities to address these issues. We welcome suggestions that could help us to achieve a more diverse and inclusive research community (see also M. Urry Nature 528, 471-473; 2015).

David McAllister, Jan Juillerat, Jackie Hunter BBSRC, Swindon, $U K$.

david.mcallister@bbsrc.ac.uk

\section{Solar energy needs focus}

The high cost of solar photovoltaic installations prevents them from providing more than about $1 \%$ of the world's electricity requirement. A solution would be to incorporate an optical concentrator in the solar photovoltaic module that would save on expensive materials without compromising electrical output.

Optical concentrators focus solar energy on a small area attached to a photovoltaic cell (P. Gleckman et al. Nature 339, 198-200; 1989). However, this technology has been held back by its complex manufacturing and assembly processes, its modest electrical-conversion efficiency and a lack of government funding and policy.

Researchers, industries and governments must work together to resolve the technical issues associated with this promising technology and come up with a practical, industry-ready design to revive the solar energy market. Abu Bakar Munir University of Malaya, Malaysia.

Firdaus Muhammad-Sukki Robert Gordon University, Aberdeen, UK; and Multimedia University, Selangor, Malaysia. Nurul Aini Bani Universiti Teknologi Malaysia, Malaysia. f.b.muhammad-sukki@rgu.ac.uk 